\title{
KONTRIBUSI PEREMPUAN MEMPERTAHANKAN KEMERDEKAAN INDONESIA DALAM NOVEL BURUNG-BURUNG MANYAR: KAJIAN KRITIK SASTRA FEMINIS
}

\author{
Sumartini $^{\bowtie}$, Maharani Intan Andalas IRP, Sara Laraswati \\ Jurusan Bahasa dan Sastra Indonesia, Fakultas Bahasa dan Seni, Universitas Negeri Semarang, \\ Indonesia
}

\section{Info Artikel}

Sejarah Artikel:

Diterima Agustus 2018

Disetujui September 2018

Dipublikasikan

November 2018

\section{Keywords:}

contributions, women,

maintaining independence,

feminist literary criticism

\begin{abstract}
Abstrak
Persoalan perempuan selalu menarik perhatian masyarakat. Novel Burung-Burung Manyar menceritakan tokoh perempuan yang bernama Larasati (Atik). Ia anak bangsawan yang menjadi perempuan modern dan mengabdikan hidupnya untuk bangsa dan negara Indonesia. Permasalahan dalam kajian ini adalah (1) bagaimanakah kontribusi perempuan mempertahankan kemerdekaan Indonesia, (2) faktor apa saja yang melatarbelakangi dialami tokoh perempuan dalam mempertahankan kemerdekaan Indonesia? Metode yang digunakan dalam kajian ini adalah metode deskriptif kualitatif. Hasil kajian ini, pertama, dalam hal mewujudkan dan mempertahankan bangsa, para perempuan mempunyai kontribusi atau sumbangan yang cukup besar. Kontribusi tersebut tidak hanya berwujud kontribusi fisik tetapi juga nonfisik. Selain itu, kontribusi yang diberikan kaum perempuan berupa kontribusi materi dan nonmateri. Kedua, ada dua faktor yang melatarbelakangi para perempuan berkontribusi dalam memperjuangkan dan mempertahankan kemerdekaan, yaitu: (1) jiwa nasionalisme, (2) cinta tanah air.
\end{abstract}

\begin{abstract}
Women's issues always attract people's attention. Novel Manyar tells a female character named Larasati (Atik). He was a nobleman who became a modern woman and devoted his life to the nation and state of Indonesia. The problems in this study are (1) how is the contribution of women maintaining Indonesia's independence, (2) what factors are behind the experience of female leaders in maintaining Indonesia's independence? The method used in this study is a qualitative descriptive method. The results of this study, first, in terms of realizing and maintaining the nation, women have a considerable contribution or contribution. The contribution is not only physical but also non-physical. In addition, the contribution made by women in the form of material and nonmaterial contributions. Second, there are two factors underlying the women contributing in fighting for and maintaining independence, namely: (1) the spirit of nationalism, (2) the love of the homeland.
\end{abstract}

(C) 2018 Universitas Negeri Semarang

\footnotetext{
Alamat korespondensi:

Gedung B1 Lantai 1 FBS Unnes

Kampus Sekaran, Gunungpati, Semarang, 50229
}

ISSN 2252-6315

E-mail: sumartini@mail.unnes.ac.id 


\section{PENDAHULUAN}

Perempuan selalu menjadi wacana menarik bagi masyarakat, baik masyarakat awam maupun akademik, bahkan menjadi isu penting yang berkembang di masyarakat. Perhatian terhadap permasalahan perempuan sudah muncul beberapa dekade yang lalu dan saat ini masih menjadi topik yang hangat. Munculnya pembicaraan tentang permasalahan perempuan ini didorong oleh keprihatinan terhadap kenyataan kecilnya peran perempuan dalam kehidupan sosial-ekonomi, politik, dan bidang pendidikan jika dibandingkan dengan peran laki-laki (Ilyas 2006: 1).

Selama ini, banyak yang beranggapan bahwa perempuan merupakan sosok yang lemah. Selain itu, perempuan dianggap sebagai makhluk irasional atau emosional sehingga perempuan tidak bisa tampil memimpin. Hal ini berakibat munculnya sikap yang menempatkan perempuan pada posisi yang tidak penting atau posisi kedua. Sementara itu, laki-laki dianggap sebagai makhluk yang pantas untuk menduduki peran penting dan dominan yang berada di posisi sentral. Perempuan hanya sebagai kanca wingking atau dalam istilah bahasa Jawanya "swarga nunut neraka katut" (Fakih 2003: 12). Perempuan dianggap sebagai makhluk yang hanya bisa macak, masak, manak. Di luar itu, semuanya merupakan pekerjaan laki-laki. Anggapan yang beredar di masyarakat tentang diri perempuan seperti itulah yang menyebabkan perempuan semakin terpinggirkan. Ironisnya, anggapan tersebut tidak hanya berasal dari kaum laki-laki, tetapi juga berasal dari kaum perempuan itusendiri.

Femomena yang terjadi di masyarakat tidak terlepas dari perhatian para pengarang, sehingga mereka merepresentasikan fenomena tersebut ke dalam karya sastra. Para pengarang, baik laki-laki maupun perempuan sering menghadirkan sosok perempuan sebagai sosok yang kuat, mempunyai peran yang tinggi atau menghadirkan sosok perempuan yang sebaliknya. Semua ini merupakan bentuk perhatian masyarakat (dalam hal ini pengarang) dalam menyikapi kenyataan atau realitas di masyarakat.

Salah satu karya sastra yang merepresentasikan masalah perempuan adalah novel Burung-Burung Manyar karya Y.B. Mangunwijaya. Novel ini menceritakan tokoh Teto dan Larasati (Atik).Teto berasal dari keluarga yang cukup terpandang, ayahnya masih keturunan bangsawan keraton, sedangkan ibunya keturunan indo-Belanda. Segala kemauan Teto selalu dituruti oleh kedua orang tuanya.
Ayahnya, Letnan Barjabasuki menjabat kepala Garnisun Divisi I di Magelang. Dengan demikian, Teto bebas bergaul dengan anak-anak Belanda maupun Indo-Belanda. Masa kecil teto benar-benar penuh kebahagiaan. Teto sangat bangga pada ayahnya. Dia juga bercita-cita menjadi tentara KNIL Belanda seperti ayahnya. Ia percaya bahwa dengan bergabung dan mengabdi pada KNIL, kehidupannya akan menjadi lebih baik. Ia akan disegani dan dihormati masyarakat.

Adapun tokoh utama perempuan, Larasati atau Atik adalah teman sepermainan Teto sejak kecil. Ia adalah seorang perempuan modern, seorang anak kesayangan yang dimanja oleh kedua orang tuanya dan juga oleh kedua orang pembantu di rumahnya. Ia anak keluarga yang cukup terpandang. Ibunya seorang perempuan keturunan darah biru, sedangkan ayahnya seorang pegawai Dinas Kehutanan. Berbeda dengan Teto, Atik tidak mau mengabdi kepada penjajah melainkan ia berjuang untuk mewujudkan dan mempertahankan kemerdekaan bangsanya. Di masa-masa genting, Atik menjadi seorang juru ketik perdana menteri Republik Indonesia.

Pengarang, melalui tokoh Atik menggambarkan bagaimana kondisi perempuan Indonesia di masa perjuangan dan masa-masa awal kemerdekaan Indonesia. Ternyata sebagian perempuan Indonesia sudah berada di garda depan perjuangan yang notabene menjadi wilayah laki-laki. Sebagai seorang perempuan, Atik tidak mau hanya berdiam diri, tetapi ikut berjuang mewujudkan kemerdekaan bangsa. Setelah Indonesia merdeka, Atik menempuh pendidikan hingga gelar tertinggi diraihnya.

$$
\text { Melalui tokoh Atik, pengarang }
$$

menyampaikan pemikirannya tentang perempuan. Tokoh perempuan (Atik) digambarkan sebagai tokoh yang cerdas, enerjik, dan dapat berkontribusi secara langsung dalam perjuangan. Banyak karya sastra yang menggambarkan perjuangan tokoh perempuan, tetapi novel karya Y.B.Mangunwijaya ini mempunyai keunikan tersendiri. Di masa pendudukan Belanda dan Jepang, perempuan pribumi belum lazim ikut berjuang. Pengarang berhasil menyampaikan pesan kepada pembaca melalui dialog tokoh-tokohnya. Selain itu, novel ini disajikan menggunakan bahasa sehari-hari yang segar, mudah dipahami, dan memperkenalkan istilah-istilah bahasa Belanda yang sering digunakan pada saat itu sehingga pembaca dapat membayangkan peristiwa yang terjadi di masa silam. 


\section{Kajian Pustaka dan Landasan Teori}

Novel ini pernah diteliti oleh Irsasri dengan judul "Novel Burung-Burung Manyar Karya Y.B. Mangunwijaya (Tinjauan Sosiologi Sastra, Perspektif Historis, dan Nilai Pendidikan)". Irsasri mengkaji novel ini melalui perspektif sosiologi pengarang, latar belakang sosial budaya, perspektif sejarah, dan nilai pendidikan yang terdapat dalam novel BurungBurung Manyar karya Y.B. Mangunwijaya.

Selain itu, novel ini juga pernah diteliti oleh Guslia Delvi pada 2011. Delvi membahas aspek psikologis (id, ego, dan superego) dari tokoh-tokoh yang ada dalam novel ini. Aspek psikologi yang berkaitan dengan id ditemukan dalam diri tokoh Teto, Atik, dan Mayor Verbruggen. Aspek psikologi tersebut berimplikasi pada ucapan kasar, tidak mau diatur, dan sikap berkhianat. Adapun aspek psikologi yang berkaitan dengan ego terdapat dalam diri tokoh Teto, Atik, dan Tuan Antana. Aspek tersebut berimplikasi pada sikap yang rasional, realistis, praktis, dan sadar akan kenyataan yang dihadapai. Sementara itu, aspek psikologi yang berkaitan dengan superego ditemukan dalam diri tokoh Teto, Atik, Mayor Verbruggen, dan Nyonya Antana. Aspek superego berimplikasi pada watak yang jujur, ikhlas, pemberani, penyayang, bijaksana, tenang, dan percaya diri.

\section{Feminisme}

Istilah feminisme dalam kajian sastra sangat berkaitan dengan kritik sastra feminis. Feminis menurut Nyoman Kutha Ratna (2004:184) berasal dari kata femme yang berarti perempuan yang berjuang untuk memperjuangkan hak-hak kaum perempuan, sebagai kelas sosial. Sejalan dengan itu, Sugihastuti (2002:18) berpendapat bahwa feminisme adalah gerakan persamaan antara laki-laki dan perempuan di segala bidang baik politik, ekonomi, pendidikan, sosial, maupun kegiatan terorganisasi yang mempertahankan hak-hak serta kepentingan perempuan.

\section{Kritik Sastra Feminis}

Kritik sastra feminis merupakan salah satu disiplin ilmu kritik sastra yang lahir sebagai respon atas berkembangnya feminisme di berbagai penjuru dunia. Kritik sastra feminis merupakan aliran baru dalam sosiologi sastra. Lahirnya bersamaan dengan kesadaran perempuan akan hak-hak yang dimilikinya.

Kritik sastra feminis banyak ragamnya dengan ciri khasnya masing-masing. Ragam kritik sastra feminis tersebut meliputi kritik sastra feminis idiologis, ginokritik, kritik sastra feminis sosialis, kritik sastra feminis-psikoanalistik, dan kritik sastra feminis ras atau etnik (Djajanegara, 2000: 28-39).

Ragam kritik sastra feminis idiologis melibatkan wanita (baca: perempuan), khususnya kaum feminis sebagai pembaca. (Djajanegara, 2000: 28). Pusat perhatian ragam kritik sastra ini adalah adalah citra dan stereotip wanita dalam karya sastra. Kritik ini juga mengkaji kesalahpahaman tentang wanita, faktor penyebab wanita sering diabaikan dan tidak diperhitungkan.

Kontribusi perempuan dalam memperjuangkan dan mempertahankan kemerdekaan Indonesia dalam novel Burung-Burung Manyar

Kontribusi mempunyai arti sumbangan (KBBI edisi V). Dengan demikian, yang dimaksudkan dengan kontribusi perempuan memperjuangkan dan mempertahankan kemerdekaan Indonesia adalah sumbangan para tokoh perempuan dalam memberi andil terhadap pencapaian kemerdekaan Indonesia dan sumbangannya dalam mempertahankan serta mengisi kemerdekaan. Dilihat dari masa atau waktu terjadinya peristiwa, paparan kontribusi perempuan dibedakan menjadi dua yaitu masa sebelum kemerdekaan dan masa sesudah proklamasi kemerdekaan.

\section{Masa sebelum kemerdekaan}

Kemerdekaan suatu bangsa merupakan cita-cita seluruh masyarakat di dunia ini. Begitu juga kemerdekaan Indonesia dicita-citakan oleh seluruh masyarakat Indonesia, baik laki-laki maupun perempuan. Kemerdekaan dapat terwujud karena adanya perjuangan dari seluruh masyarakat Indonesia. Perjuangan itu dapat berwujud perjuangan fisik ataupun nonfisik.

Kontribusi perjuangan yang tergambar dalam novel ini bisa dilihat pada tokoh-tokoh perempuan, yaitu $\mathrm{Bu}$ Antana (Ibunda Atik) dan Atik serta tokoh-tokoh bawahan lainnya. Perempuan memiliki andil yang sangat besar dalam memperjuangkan dan mewujudkan kemerdekaan. Sumbangan kaum perempuan tidak semata-mata berupa sumbangan fisik, yaitu ikut bertempur melawan penjajah, melainkan sumbangan nonfisik. Para perempuan, seperti yang digambarkan oleh tokoh $\mathrm{Bu}$ Antana memberi pengaruh yang besar bagi perjuangan suaminya dalam berjuang meraih kemerdekaan. $\mathrm{Bu}$ Antono memberi kepercayaan penuh kepada suaminya yang sering pergi di luar jam kantor untuk ikut bergerilya bawah tanah walaupun suaminya tidak berterus terang kepadanya tentang aktivitas yang dilakukan. Bu Antono 
percaya bahwa apa yang dilakukan suaminya adalah hal besar yang akan ikut mengubah nasib bangsa. Hal tersebut mengisyaratkan bahwa $\mathrm{Bu}$ Antono mempunyai sikap dan jiwa nasionalisme, yaitu sebuah semangat yang menjadi ruh perjuangan untuk memperoleh kemerdekaan. Hal tersebut terlihat dalam kutipan berikut ini.

"Besok pagi, kan pulang."

"Ke Cipanas lagi?"

"Sangat mungkin." Bu Antana bernafas panjang. Cita rasanya merasa intuitif, suaminya menyembunyikan sesuatu. Bukan. Bukan soal perempuan lain. Tapi soal politik. Sama bahayanya dengan masalah cinta segitiga...Tetapi sudah setahun ini, lebih-lebih dalam bulan-bulan Juni-Juli suaminya sering, ya jelas terlalu sering, mendadak di luar program rutin pergi entah ke mana, Bogor, ke Cipanas, ke entahlah. Pasti ada sangkut pautnya dengan politik. Dan Bu Antana tahu, politik di bawah tanah. Dalam batin Bu Antana hanya berdoa agar semua selamat.

Ia percaya suaminya tidak akan berbuat gegabah atau yang bukan-bukan. Bukan orang emosional dia, jenis pemikir tenang. (BbM:56)

Kepercayaan seorang isteri kepada suaminya menjadi hal penting untuk mendukung keberhasilan suami dalam berjuang bersama masyarakat lainnya. Tanpa dukungan penuh dari isterinya, Pak Antana tidak akan bisa ikut bergerilya di masa revolusi. Meskipun Pak Antana tidak menceritakan semua peristiwa kepada isterinya, $\mathrm{Bu}$ Antono sangat memahami sikap tertutup suaminya. Bu Antono percaya, hal ini dilakukan suaminya untuk menjaga keamanan dan keselamatan keluarganya.

$\mathrm{Nah}$, kalau sudah sampai sekian, intuisi $\mathrm{Bu}$ Antana maklum bahwa suaminya memang sedang mengerjakan sesuatu aksi politik di bawah tanah. Ia tidak pernah bertanya lebih lanjut. Kepercayaan putri jawanya yakin bahwa bila memang perlu, suaminya akan menceritakannya dengan sendirinya.

Tetapi kalau dia diam, itu jelas juga ada alasannya yang sah. Dan Bu Antana yakin lagi. Itu juga pasti demi keselamatan sang istri dan anak. Zaman Kempetai bukan sesuatu yang bisa dijadikan permainan anak-anak. Ah, semogalah selamat. Apa yang bisa diperbuat perempuan selain berdoa? Ditambah membuat sambal goreng taoco, kesenangan suaminya? (BbM:59) Dari kutipan di atas, dapat diketahui kontribusi lain dari $\mathrm{Bu}$ Antono adalah selalu mendoakan suaminya yang berjuang bersama rakyat Indonesia untuk meraih kemerdekaan supaya selamat dan selalu dalam lindungan Allah disertai sikap pasrah dan tawakal kepada Allah Sang Pencipta. Dalam kehidupan ini, doa merupakan satu komponen penting yang tidak dapat dipisahkan dari perjuangan hidup manusia. Untuk itulah, kesadaran Bu Antono untuk mendoakan suaminya dan keluarganya merupakan sumbangan yang besar dalam keberhasilan perjuangan suaminya. Perjuangan tanpa doa, bisa diibaratkan seperti dua sisi mata uang yang tidak dapat dipisahkan antara satu dengan yang lain.

\section{Masa awal-awal kemerdekaan}

Masa awal-awal kemerdekaan

merupakan masa sulit bagi bangsa Indonesia.

Bangsa yang masih sangat muda ini tentu saja membutuhkan orang-orang yang mempunyai kecerdasan intelektual dan jiwa nasionalis yang tinggi. Salah satu perempuan yang cukup cerdas dan intelek adalah Atik, anak dari keluarga Pak Antana. Pada masa pendudukan Jepang, Atik, gadis yang sangat cerdas ini dapat bersekolah sampai tingkat SMT (Sekolah Menengah Tinggi). Hal ini didukung oleh kondisi keuangan dan perekonomian yang baik dari orang tuannya serta kecerdasan yang ia miliki yang menurun dari ayahnya, Pak Antana. Di masa Jepang ayahnya adalah salah satu pegawai di Dinas Kehutanan.

Sejak masih muda, pada usia sekitar 17 tahun Larasati (Atik) sudah ikut berjuang dalam pergulatan diplomasi menghadapi dunia internasional demi kemenangan dan kemerdekaan bangsanya. Walaupun hanya sebagai sekretaris (juru ketik) yang masih sangat muda di bawah bayangan para garuda dan elang diplomat tinggi, namun Atik mempunyai semangat membara untuk mengabdi kepada bumi pertiwi dilandasi kecerdasan dan keberanian yang dia miliki. Hal tersebut dapat dilihat pada kutipan berikut ini.

....Ayah dan Atik sekarang menyumbang seapaadanya di kantor perdana menteri RI. Atik Cuma jadi juru ketik yang tak punya arti. Ayah bertugas entah, sering kian kemari Yogya-Jakarta. (BbM:86)

Sekretaris atau juru ketik merupakan satu tugas mulia dan mempunyai peran strategis di kantor perdana menteri. Seorang sekretaris mempunyai tugas berat, ia menjadi tulang punggung untuk mengarsipkan berbagai peristiwa penting dan semua hal terutama hal-hal yang berkaitan dengan diplomasi.

Sebagai gadis yang masih muda belia, apa yang dilakukan oleh Atik ini merupakan sumbangan yang sangat berharga dalam memperjuangkan dan mempertahankan 
kemerdekaan. Jarang sekali perempuan yang mempunyai keberanian dan kecerdasan seperti Atik. Dengan penuh kekaguman dan ketekunan ia menjalani tugasya sebagai seorang sekretaris dan selalu menyertai ke mana pun pimpinannya pergi melakukan diplomasi. Hal tersebut dapat dilihat pada kutipan yang dituturkan oleh tokoh Teto berikut ini.

....."Ya, sayang," aku meyakinkan diriku lagi, walaupun sebenarnya tidak sangat yakin, sebab di belakang orang kecil tadi aku melihat seorang gadis, yang sedang mengetik entah apa, seorang juru ketik muda yang barangkali masih hijua tunas, tetapi yang penuh takjub selalu memandang kepada pemimpinnya, perdana menteri paling muda di dunia dari negara yang paling muda di dunia pula. (BbM:95)

Atik menjadi sekretaris masih dalam usia yang sangat muda. Perdana menteri yang menjadi pimpinannya adalah perdana menteri paling muda di dunia, begitu juga bangsa tempat mengabdikan diri juga menjadi bangsa yang paling muda. Namun demikian, apa yang dilakukan Atik adalah hal besar yang menentukan nasib bangsa. Sebagai sekretaris, ia tidak hanya bertugas sebagai juru ketik atau pencatat saja. Ia juga bertugas sebagai penerjemah hasil diplomasi dari bahasa Indonesia ke bahasa Inggris atau sebaliknya dari bahasa Inggris ke bahasa Indonesia. Hal ini merupakan tugas yang sangat berat dan mulia yang tidak dapat dilakukan oleh semua orang, khususnya kaum perempuan. Pada masa itu, belum banyak kaum perempuan yang menempuh pendidikan tinggi seperti Atik, walaupun jumlah perempuan yang mengikuti delegasi sudah cukup banyak. Sebagian besar perempuan yang ikut dalam delegasasi masih berpendidikan rendah sehingga tidak dapat membantu dalam bidang yang membutuhkan pemikiran tingkat tinggi.

Larasati hanya penyumbang kecil di dalam medan perjuangan itu. Penerjemah tekateki diplomasi ke dalam bahasa Inggris dan sebaliknya memang dibutuhkan mutlak, tetapi itu pekerjaan dinas saja. Para pembantu wanita dalam delegasi Indonesia tahu banyak, tetapi juga sedikit sekali." (BbM :140)

Atik mempunyai tugas rangkap, yaitu sebagai sekretaris sekaligus penerjemah bahasa. Pekerjaan sebagai penerjemah bahasa merupakan pekerjaan penting dalam kegiatan diplomasi. Seharusnya tugas ini tidak dirangkap oleh sekretaris. Akan tetapi, karena para perempuan dan rombongan yang ikut dalam delegasi masih sangat terbatas kemampuannya, akhirnya tugas sebagai penerjemah diemban juga oleh Atik yang mempunyai kemampuan untuk tugas tersebut.

Masa-masa awal kemerdekaan, bangsa Indonesia belum aman dan masih menjadi masa sulit bagi rakyat Indonesia dan para pejuang. Serangan-serangan dari Belanda masih sering terjadi. Pak Antana sebagai pejuang, masih ikut terus berjuang. Suatu pagi di bulan Desember dalam perjalanan menuju ke Yogya bersama Atik, Pak Antana tewas tertembak oleh musuh. Sejak kepergian Pak Antana, Bu Antana dan Larasati (Atik) ikut bekerja di dapur umum mengabdikan diri bagi perjuangan bangsa yang belum selesai.

Sejak itu, ibu dan putri bekerja bakti di dapur umum para gerilyawan di suatu desa di seberang jurang Juranggede yang bernama Grojogan. Tugas di dapur berat secara fisik, tetapi dari segi penyegaran jiwa tak berarti. Sebab begitu lalu mereka tak merasa sebagai pengemis yang hanya menerima pengayoman tanpa imbalan. Tanpa dapur umum perjuangan para gerilyawan mustahillah. Dan selalu saja dan pekerjaan atau tugas mendadak yang lekas-lekas harus diselesaikan. (BbM:207)

Sejak Pak Antana meninggalkan mereka untuk selamanya, ibu dan anak ini tidak tinggal di kota. Untuk sementara waktu merekamengungsi dan tinggal di daerah pegunungan berbaur dengan masyarakat untuk meneruskan perjuangan melalui kegiatan memasak di dapur umum. Pekerjaan di dapur umum memang menguras tenaga fisik yang banyak. Akan tetapi, Bu Antana dan Atik merasa senang dapat bekerja dan membantu pekerjaan di dapur umum. Mereka bangga dapat berperan aktif dalam perjuangan dengan menyumbangkan tenaganya di dapur umum. Terlebih lagi bagi $\mathrm{Bu}$ Antana yang mempunyai kepandaian memasak dapat menyalurkan hobinya dan menghibur dirinya yang bersedih karena kepergian suaminya. Dengan membantu di dapur umum, mereka tidak merasa sebagai pengemis yang hanya menerima pengayoman dari masyarakat serta menjadi beban hidup bagi masyarakat. Mereka merasa menjadi manusia berharga yang masih dapat berperan serta dalam mengisi kemerdekaan Negara yang masih sangat muda ini.

Dengan bekerja di dapur umum, Bu Antana dan Atik merasa lebih segar dan sehat secara jasmani rohani. Secara jasmani mereka bekerja mengeluarkan keringat sehingga fisik mereka menjadi sehat. Secara rohani mereka merasa bahagia karena dekat dengan tempat pemakaman Pak Antana, sehingga setiap saat mereka dapat mengunjungi makam. 
Setelah keadaan menjadi semakin baik dan Indonesia diakui kemerdekaannya oleh masyarakat internasional, Bu Antono dan Atik kembali ke kota. Atik tetap mengabdikan diri bekerja kepada pemerintah tetapi tidak sebagai sekretaris di Departemen Luar Negeri, melainkan memilih bekerja di Dinas Kehutanan. Keputusan ini diambilnya berdasarkan pertimbangan untuk meneruskan pekerjaan ayahnya dan pekerjaan ini lebih sesuai dengan dirinya yang lebih menyukai alam.

"Apa lagi, Tik!" Di Kementerian Luar Negeri kariermu bisa terjamin."

"Aku seolah mendengar pesan ayah, Bu."

Tubuh anaknya ditarik dan dirangkulnya. Berdebar-debar jantung Jawa sang Ibu apa yang akan dikatakan anaknya itu.

"Aku ingin meneruskan pekerjaan Ayah. Di Dinas Kehutanan, Bu." (BbM:218)

Menanggapi keputusan anaknya, $\mathrm{Bu}$ Antana mendukung sepenuhnya keputusan Atik untuk tetap mengabdi kepada bangsa dan negara walaupun berbeda dengan bidang pekerjaan Atik sebelumnya. Bu Antana merasa, bahwa pilihan Atik ini merupakan pilihan yang tepat dan sesuai dengan jiwanya karena sejak kecil Atik sudah tertarik pada lingkungan dan alam. Hal tersebut merupakan warisan dari ayahnya yang sudah mendarah daging sejak kecil. Keputusan Atik untuk mengabdikan diri di Dinas Kehutanan merupakan pilihan yang sangat tepat. Di tempat baru ini karirnya berkembang dengan cepat dan cemerlang. Walaupun perempuan, ia dapat menduduki jabatan sebagai Kepala Direktorat Pelestarian Alam. Sebuah jabatan yang masih langka bagi perempuan pada saat itu. Untuk mengembangkan ilmunya, Atik tidak puas hanya dengan bekerja di kantornya, tetapi ia juga meneruskan studinya hingga menempuh pendidikan doktor di salah satu universitas terkemuka di Yogyakarta dan berhasil lulus dengan predikat maxima cumlaude.

Pagi itu Nyonya Janakatamsi, Kepala Direktorat Pelestarian Alam, akan mempertahankan tesisnya untuk meraih gelar doktor biologi di hadapan Senat lengkap beserta undangan...(BbM:305)

Selamat datang kepada hadirin-hadirat yang mulia, dari jurusan mana pun, sebab tesis yang harus dipertahankan doktoranda ini menyangkut kita semua juga. Judul disertasi yang diajukan oleh Dra. Larasati Jakatamsi sungguh sejalan dengan jabatan doktoranda selaku Kepala Direktorat Pelestarian Alam, yakni "Jati Diri dan Bahasa Citra dalam Struktur Komunikasi Varietas Burung Ploceus Manyar." Seorang profesor di samping Rektor bertepuk tangan, yang disusul oleh spontanitas tepuk tangan hadirin-hadirat. Termasuk aku juga. (BbM:310)

Keberhasilan Atik dalam karir dan capaian gelar tertinggi dalam pendidikan merupakan kontribusi yang sangat berharga dalam mempertahankan dan mengisi kemerdekaan bangsa dan negara. Bangsa yang sudah merdeka membutuhkan orang-orang cerdas dan berkomitmen tinggi serta berjiwa nasionalis. Atik, sebagai seorang perempuan telah memberikan sumbangan yang besar bagi bangsa dan negaranya serta keluarganya.

Faktor-faktor yang menjadi latar belakang tokoh perempuan berkontribusi memperjuangkan dan mempertahankan kemerdekaan Indonesia dalam novel BurungBurung Manyar

Dalam pembahasan rumusan masalah yang kedua ini dipaparkan mengenai latar belakang para tokoh perempuan berkontribusi dalam memperjuangkan dan mempertahankan kemerdekaan yang terdapat dalam novel Burungburung Manyar. Dari hasil analisis ditemukan dua faktor yang meletarbelakangi hal tersebut, yaitu (1) sikap nasionalisme; (2) cinta tanah air.

Atik, gadis remaja yang berasal dari keluarga ningrat. Ayahnya seorang pegawai di Dinas kehutanan, sedangkan ibunya keturunan bangsawan Solo. Sebagai anak seorang bangsawan dan berkecukupan, Atik dididik dalam pendidikan formal, dia disekolahkan di sekolah Belanda. Kecerdasan Atik yang menurun dari ayahnya sudah terlihat sejak kecil dan terus terasah. Kecerdasannya tersebut berpengaruh besar terhadap munculnya rasa nasionalisme dalam dirinya. Pada saat masih sekolah menengah tinggi, Atik sudah mempunyai semangat membara untuk ikut berperan serta dalam meraih kemerdekaan. Dalam jiwanya telah tertanam rasa nasionalisme yang tinggi. Sering ia bercerita dengan penuh semangat tentang semangat Bung Karno yang menggelora. Selain itu, Atik juga sering berdiskusi bersama keluarganya dengan penuh rasa optimis dan tegas.

"Kalau Indonesia kelak merdeka, Negara kita tidak akan kejam."

"Mudah-mudahan, Tik."

"Tidak boleh mudah-mudahan, Pap. Harus." Atik memang sudah menjadi pemudi yang bergelora. Api pijar Bung Karno sudah menyala di dalamnya. (BbM:58)

Dari kutipan di atas dapat diketahui bahwa Atik muda sudah mempunyai cita-cita untuk kemerdekaan Indonesia dan bagaimana seharusnya kalau Indonesia sudah merdeka. 
Selain kepada ayah dan keluarganya, Atik juga sering berdiskusi tentang kemerdekaan Indonesia kepada Teto. Mereka sering berbeda pendapat dalam hal tersebut seperti yang diungkapkan tokoh Teto dalam kutipan berikut ini.

Di zaman Jepang kita berselisih paham mengenai orator kolaborator Jepang, tetapi juga seumumnya tentang apa yang kau sebut cita-cita kemerdekaan dan sebagainya. Aku sungguh tidak mudeng. Larasati, kau yang raden ayu dari puri Surakarta, dengan napas keluarga raja Jawa yang paling modern dan paling setia kepada ratu Belanda, mengapa Atik begitu naif berbicara macam-macam impian bangsa yang hanya impian saja?...(BbM:82)

Dari kutipan di atas dapat diketahui bahwa Atik mempunyai pemikiran yang berbeda dengan Teto. Keluarga besar Atik adalah keluarga ningrat yang sangat tunduk patuh kepada pemerintah Belanda. Namun, Atik mempunyai semangat dan cita-cita yang berbeda dengan keluarga ningrat pada umumnya. Dalam diri keluarga Atik, khususnya Atik telah tumbuh semangat nasionalisme yang tinggi. Mereka ingin mempunyai negara yang merdeka tidak dikuasai oleh bangsa lain. Hal ini berbeda dengan Teto yang sama-sama menempuh pendidikan tinggi. Dalam diri Teto tidak muncul semangat nasionalisme, justru ia ingin mengabdi pada pemerintah Belanda dan menjadi tentara KNIL.

Nasionalisme dapat diartikan sebagai (1) paham atau ajaran untuk mencintai bangsa sendiri ; (2) kesadaran keanggotaan dalam suatu bangsa yang secara potensial atau aktual secara bersama-sama mencapai, mempertahankan, dan mengabadikan identitas, integritas, kemakmuran, dan kekuatan bangsa itu ((KKBI V). Nasionalisme yang muncul pada diri Atik dan keluarganya sangat mungkin terwujud karena ada kesadaran untuk mencintai tanah air sendiri. Dari pengalaman mereka selama dijajah Belanda dan Jepang, memunculkan kesadaran baru untuk ikut berjuang mendirikan negara baru, yaitu Indonesia.

$\mathrm{Bu}$ Antana tidak tahu banyak tentang bintang-bintang politik masa baru, maklumlah ia terlalu orang pingitan puri ningrat. Tetapi dalam satu perkara seluruh keluarga bersatu teguh: mereka tidak senang kepada Jepang. Artinya kepada kaum militer kejam itu. Suaminya selalu berkata,"Kita harus membedakan antara Jepang sebagai bunga kebudayaan yang tinggi, seperti Cina, India, Arab, dan lain-lain dan dari pihak lain: kekejaman para kaum samurai itu."

Dari kutipan di atas, diketahui bahwa keluarga Pak Antana sudah memiliki kesadaran untuk merdeka ketiga bangsa ini dikuasai
Jepang. Pak Antana sudah merasakan penderitaan selama dijajah Belanda dan Jepang. Sebagai orang yang berpendidikan tinggi dan bekerja sebagai pegawai pemerintah, Pak Antana mempunyai kesadaran yang berbeda dengan para pegawai pemerintah lainnya. Kepada keluarganya, Pak Antana menekankan bahwa Belanda dan Jepang sama-sama penjajah sehingga keluarga mereka tidak boleh takjub melihat kebaikan Jepang kepada rakyat Indonesia. Kebaikan yang ditunjukkan Jepang hanya pada kulit luarnya saja karena sebenarnya Jepang juga ingin menguasai bangsa ini dan menjadikan rakyat bangsa ini sebagai sapi perah. Bahkan, Jepang lebih kejam dari Belanda. Banyak kaum laki-laki dari bangsa ini yang dijadikan romusha (budak kerja paksa) tanpa diberi upah dan kemungkinan besar tidak bisa kembali ke rumah seperti yang dialami oleh anak laki-laki Mbok Inem, pembantu mereka.

...."Mbok Inem menderita," sambung isterinya lagi. Anaknya diberangkatkan sebagai romusha. Mengapa sampai terjadi itu?" Romusha kan boleh pulang kelak, Pak?"

"Ya, selalu saja itu mungkin." [dan nada getir sinis]. "Istilah sekarang: kelak di kemudian hari." (BbM:62)

Apa yang dialami oleh pembantu mereka dan rakyat pada umumnya, menumbuhkan semangat untuk berjuang mewujudkan kemerdekaan. Perjuangdan dan pemikiran Pak Antana sangat berpengaruh terhadap isteri dan anaknya, sehingga mereka menjadi satu keluarga yang punya jiwa nasionalsime yang dilandasi cinta tanah air.

Penutup

Berdasarkan pembahasan di atas dapat diambil simpulan berikut ini. Pertama, dalam hal mewujudkan dan mempertahankan bangsa, para perempuan mempunyai kontribusi atau sumbangan yang cukup besar. Kontribusi tersebut tidak hanya berwujud kontribusi fisik tetapi juga nonfisik. Selain itu, kontribusi yang diberikan kaum perempuan berupa kontribusi materi dan nonmateri. Kedua, ada dua faktor yang melatarbelakangi para perempuan berkontribusi dalam memperjuangkan dan mempertahankan kemerdekaan, yaitu: (1) jiwa nasionalisme, (2) cinta tanah air.

\section{Daftar Pustaka}

Delvi, Guslia. 2011. "Psikologis Tokoh Novel Burung-Burung Manyar Karya Y.B. Mangunwijaya". Skripsi. FKIP PSPBSI IKIP Riau. 
Djajanegara. Soenarjati. 2000. Kritik Sastra Feminis Sebuah Pengantar. Jakarta: Gramedia Pustaka Utama.

Fakih, Mansoer. 2003. Analisis Gender \& Transformasi Sosial. Yogyakarta: Pustaka Pelajar

Ilyas, Yunahar. 2006. Kesetaraan Gender dalam AlQur'an, Studi Pemikiran Para Mufasir. Yogyakarta: Labda Press.

Irsasri. 2011. "Novel Burung-Burung Manyar Karya Y.B. Mangunwijaya (Tinjauan Sosiologi Sastra, Perspektif Historis, dan Nilai Pendidikan"). Tesis. Pascasarjana Universitas Negeri Sebelas Maret.

Kamus Besar Bahasa Indonesia Edisi V.

Ratna, Nyoman Kutha,S.U. 2004. Teori, Metode, dan Teknik Penelitian Sastra dari Strukturalisme hingga Postrukturalisme. Yogyakarta: Pustaka Pelajar.

Sugihastuti dan Sugiharto. 2002. Kritik Sastra Feminis: Teori dan Aplikasinya. Yogyakarta: Pustaka Pelajar

Tong, Rosemarie Putnam. 2005. Feminist Thought: Penerjemah Aquarini Priyatna Prabasmoro. Yogyakarta: Jalasutra. 